\title{
Profiles of Pre-service Teacher Education: An Investigation into the Nature of Selected Exemplary Programs in Jamaica and Michigan
}

\author{
Heather Smith-Sherwood ${ }^{1}$ \\ ${ }^{1}$ Department of Graduate Education and Leadership, College of Education and Leadership, Northern Caribbean \\ University, Mandeville, Jamaica West Indies \\ Correspondence: Heather Smith-Sherwood, Department of Graduate Education and Leadership, College of \\ Education and Leadership, Northern Caribbean University, Mandeville, Jamaica West Indies. E-mail: \\ micheath96@gmail.com
}

Received: July 25, 2017 Accepted: September 5, $2017 \quad$ Online Published: December 21, 2017

doi:10.5539/jel.v7n2p139 URL: http://doi.org/10.5539/jel.v7n2p139

\begin{abstract}
This qualitative multi-case study investigated thre exemplary pre-service teacher education programs in Jamaica and Michigan in order to provide an account of how they are structured in different contexts of tertiary institutions and, to identify how they ensure that their graduates are prepared to function effectively in today's schools. Five categories of stakeholders across the three institutions were interviewed regarding their perception and expectations of pre-service teacher education in general as well as in the context of their program. The responses from these persons were described in narrative form, then analyzed and compared based on the similarities and differences that existed among them. The analysis led to the emergence of various themes across the three institutions, and these were used to draw conclusions relative to the structure of pre-service teacher education. The findings revealed eight distinguishing features of exemplary/effective pre-service teacher education programs whether university or college-based. (a) coherent program vision (b) cultural competence (c) collaborative partnership (d) contextualization (e) quality standards (f) well-planned and implemented field experiences (g) continuous assessment (h) experienced committed faculty and (i) a harmonious blend of theory and practice. To be effective, pre-service teacher education programs must prepare prospective teachers to adequately meet the challenges of teaching in today's classrooms. To effect change, quality teachers are needed, and to produce quality teachers, quality preparation is a necessity.
\end{abstract}

Keywords: college supervisors, cooperating teacher, field experience, lecturers, pre-service teacher education, teacher education, teacher educators, teacher graduates, professors, practicum

\section{Introduction}

"Education is an important investment in human capital, and plays an important role in helping people learn to become literate, numerate, problem-solvers and motivated toward self-realization, economic sufficiency, civic responsibility and satisfactory human relationships" (Brimley \& Garfield, 2002, p. 1). In speaking to the American Government in July 2000, Allan Greenspan (as cited in Brimley \& Garfield, 2002) said the nation must invest in human capital and, as such, it is critical that the quality of education in elementary and secondary schools be improved. He declared:

Even the most significant advances in information and technology will not produce additional economic value without human creativity and intellect. Certainly, if we are to remain preeminent in transforming knowledge into economic value, the U.S system of education must remain the world's leader in generating scientific and technological breakthroughs and in preparing workers to meet the need for skilled labor. ... Education must realize the potential for bringing lasting benefit to the economy. (p. 2)

The current situations which exist in the United States and Jamaica are sufficient to awaken a consciousness in the leaders regarding the urgent attention that must be paid to schooling and teacher education. These must be regarded as high-priority items. The stark reality however is that the concerns of teacher educators relative to the interrelatedness of schooling and teacher education are not shared by the general populace. In fact, Sikula (1996) remarked that health care, violence and the economy are more highly prioritized than education. 
Over the last two to three decades, violence has eroded the social fabric of the Jamaican society. In recent years, the education system has come under serious attack, as this situation has escaped into schools especially at the secondary level. Jamaican Daily Gleaner ("Violence in Schools," 2004) reports a list of violent incidents in Jamaican schools involving students with their peers as well as with teachers, administrators, and other stakeholders. This was just a sample of the many incidents that had disrupted the system since the beginning of the calendar year 2004.

Writing in Institute of Education Annual, King (2000) observes, "Violence is fast becoming the accepted way of solving conflicts in the wider national and global society as well as in the school community" (p. 5). The close proximity of Jamaica to the US, she notes, with its estimated school-related violence of 204,000 incidents of aggravated assaults, 270,000 burglars, 12,000 armed robberies, and 9,000 rapes annually, must be regarded as a contributing factor.

In conducting a systems analysis, the government of Jamaica identifies acute economic pressures as contributing negatively to the stability of the country. There are reductions in public expenditure on education, high levels of functional literacy, low levels of morale, and the unpreparedness of graduates of the education system to deal with the challenges of the work environment as the underlining cause of the erosion of quality and severe inefficiencies relative to the education sector (King, 1998).

Sikula (1996) writes that in comparison to other industrialized countries, the United States is ranked number one in social issues such as murders, incarceration, capital punishment, homelessness, single-parent families, television watching and divorce. Citing Frank and Marie Hill, King (2000) identifies nine societal factors that the writers recognize as associated with high incidence of violence in US schools: dysfunctional families, clashes of cultures and lack of community, media messages, prevalence of weapons, denial, cover up, and court systems, drugs as big business, gangs and other subculture activities, catalytic events and random violence (p. 11). These, King further reports, are not unique to the US; they are also prevalent in other countries as well as in Jamaica.

In an age when social problems have escalated to epidemic proportions, Sikula (1996) and O'Hare \& Odell (1995) advocate that educators must become more willing to serve as advocates and change agents, no longer accepting the roles of impartial observers and transmitters of culture. Jennings (2000) examined therefore the National Educational Policy documents in the Caribbean and note that they are strong regarding the teacher as a leading change agent of educational reform. Further, she emphasized that the Barbados White Paper on Educational Reform proclaims "teacher empowerment" as a central plank in the strategy aimed at improving the educational quality for all students. This is so reflective of the developmental trend in Caribbean Teacher Education.

Among other things, a country's education system is directly related to and influenced by the caliber of teachers by which it is served. Teachers are in turn influenced by the training received. The training received is a function of the training programs, which are influenced by philosophy, vision, governance, and structure. According to Guyton (2000), powerful teacher education programs will produce good teachers who are able to teach all the students who come to their class. If the program is effective, Guyton believes it will have a positive effect on teachers and ultimately on their students.

Fullan (1995) suggests that quality learning for all students depends, on quality learning for all teachers. This, he believes, is dependent on the development of the six interrelated domains of teaching and learning - collegiality, context expertise, continuous learning, change process, and moral purpose. The ultimate goal of all educational endeavors must be student learning; consequently, teacher education can and must be made accountable for making connections between teacher performance and student learning.

In respect of this connection, the National Commission on Teaching and America's Future articulated the following position:

1) What teachers know and can do is one of the most important influences on what students learn.

2) Recruiting, preparing and retaining good teachers are the central strategy for improving schools.

3) School reform cannot succeed unless it focuses on creating the conditions in which teachers can teach and teach well. (Miller, 1999, p. 63)

Kostner \& Dengerink (2001) make the connection even more explicit; they say:

The quality of teaching depends in large measure on the quality of the teachers, the quality of the teachers depends in large measure on the quality of their professional development, the quality of teacher education depends in large measure on the quality of those who provide it -namely the teacher educators. (p. 345) 
It is therefore imperative that schooling and teacher education be given national priority, as there is no question to the fact that there is a direct relationship between the social and economic state of a country and its education system (Brimley \& Garfield, 2002). Teachers must be properly trained to become change agents. Orlofsky (2001) advocates that teacher education must be time-tested and redefined in order that young teachers are adequately prepared as dynamic, creative individuals, ready for the realities of the teaching profession in a $21^{\text {st }}$-century society.

The need for teacher education to reassess its effectiveness in light of this startling reality that impacts the education system is paramount. Studies show that teacher preparation is critical to student success, and good teacher preparation can result in the kind of delivery that will lead to improvements in students' outcomes (Byrd \& McIntyre, 1997; Sikula, 1996) and therefore a transformation in the entire education system.

Within the context of the challenges facing schooling and the education system and the critical role of teacher education in transforming teaching through the proper preparation of teachers, this study investigated and provides an in-depth account of how pre-service teacher education is structured and conducted in three different contexts of tertiary institutions in the country of Jamaica and the state of Michigan. The study also sought to examine the expectations of teacher education students in light of these challenges and the preparations that their program must afford.

\section{The Context of the Problem}

The following represents a brief overview of the structure of teacher education in Jamaica and Michigan, the two areas that form the context for the development of this study.

\subsection{The Jamaican Context}

Teacher education in Jamaica falls under the governance of the University of the West Indies and is directed by the Joint Board of Teacher Education. This regional board has a secretariat and is a partnership body with teacher training colleges or institutions charged with the responsibilities of executing teacher education programs, teachers' organizations in the three affiliated countries, independent members, Ministries of Education, and the Faculty of Humanities and Education at the University of the West Indies.

The mission of the Joint Board is to guarantee quality in teacher education in the Western Commonwealth Caribbean. At the end of their training, the Board notes that teachers must possess the necessary competencies to take their place as leaders in society. Within this context, the environment of teacher education is expected to provide rich opportunities for students and educators to be involved in:

1) cooperative learning process

2) reflective activities that promote self and peer analysis

3) inquiry and problem-solving activities

4) learner-centered processes

5) exposure to principles of relevant theories of learning (Joint Board of Teacher Education, 2003, p.

3).

The Joint Board certifies teachers who are trained at the undergraduate level in colleges in the Bahamas, Belize, and Jamaica. Those who are certified by the Board are automatically recognized by the University of the West Indies and the Ministries of Education of the three countries. Certification indicates that through the process of external examination and accreditation, this person has acquired the necessary academic and professional skills necessary for teaching.

There are five programs through which the Joint Board certifies teachers. These are: Early Childhood Education, Special Education, Primary Education, Secondary Education, and Literacy Studies. The Early Childhood Program prepares students to teach children between the ages of 3 and 7. The Primary Program prepares students to teach children between the ages of 6 and 12, that is, from Grades 1 to 6 .

The Secondary Program prepares students to teach specified subjects to adolescents between the ages of 12 and 17, that is, from Grades 7 to 11 or forms 1 to 5. The Special Education Program prepares students to teach children between the ages 3 and 14 who are challenged in one or more of the following ways; Hearing Impaired, Visually Impaired, Mentally Challenged, or Learning Disabled (Joint Board of Teacher Education, 2003).

Pre-service, undergraduate education is generally offered at the college level where programs are delivered over a 3-year period. In other instances, however, students can be awarded advanced placement, and in this case their 
period of training is reduced to 1 or 2 years depending on the nature of the placement. Teachers are certified through the award of certificates and diplomas.

The process of external assessment is done during the latter part of the 3rd year field experience. This is conducted by representatives of the Joint Board of Teacher Education in collaboration with the college supervisors. External assessment provides for the verification of teacher competence and for students' certification.

\subsection{The Michigan Context}

According to Michigan law, teachers of elementary or secondary schools must be certified for the positions for which they are assigned. This certification is made compliant by the Office of Professional Preparation Services (OPPS) in the Michigan Department of Education. It is the responsibility of this office to ensure that all professionals within the school environment complete quality preparation and professional development, in keeping with the standards that are articulated by the Michigan Legislature, the State Board of Education, and the Superintendent of Public Education (Michigan Department of Education, 2003).

In Michigan, as well as in other states, a teaching license is obtained through the completion of a college or university teacher education program. This program however must be approved by the Michigan Department of Education (MDE). The State Board of Education is required by law to determine the requirements and to issue the licenses and certificates for all public school teachers. A license indicates that such an individual has met state mandated requirements and is approved to practice in the state (Michigan Department of Education, 2003).

The Michigan law states that no person shall be eligible to teach in any private, denominational, or parochial school without a teaching certificate. State mandates also include ensuring that teacher preparation is aligned to student standards.

The Michigan State Board issues two types of certificates: the Provisional Certificate and the Professional Education Certificate. The Provisional Certificate is earned by successful completion of an approved teacher education program for a specialized area. This certificate is valid for a period of up to 6 years within which time the teacher is expected to gain experience and additional professional development for the next level of certification.

The Professional Education Certificate is the advanced teaching credential, which is earned after the issuance of the Provisional Certification. The teacher must acquire at least 3 years of experience as a practicing teacher in addition to the successful completion of 18 semester hours of additional study. For elementary certification, the teacher must complete 6 semester hours of reading requirement, while those for secondary certification are required to complete 3 hours (Michigan Department of Education).

The Michigan Test for Teacher Certification (MTTC) is also a mandated requirement for teacher certification. The purpose of the tests is to ensure that each certified teacher possesses the necessary basic skills and content knowledge to operate in Michigan Public Schools. The MTTC consist of three tests.

The Basic Skills Test comprising reading, mathematics, and writing has to be successfully completed by students before they are enrolled into student teaching. For the Academic Content-area Tests, candidates for secondary-level teaching certificates must pass the corresponding subject area test for each academic content area in which they are to be certified. Elementary Education Test has to be completed successfully by those teachers who wish to teach in elementary classrooms. Those who wish to teach in Grades 6-8 in specific subject areas are expected to pass the appropriate subject-area tests in order to qualify for endorsement (Michigan Department of Education, 2003).

\subsection{Theoretical Considerations}

The future of our children, according to Pacheco (2000), depends on better teachers, which lead to better schools, which lead to better children, and which will eventually lead to a better democracy.

Researcher, Orlofsky (2001) is convinced of the efficacy of studying time-tested models of teacher preparation programs in order to make application to current pedagogical situations. Goodlad (1994) shares the view that a new model of school and school reform is needed, and future educators must be specially prepared with the relevant expectations, knowledge, and skills to participate effectively in the renewing process.

A major responsibility of teacher education is to facilitate professional self-reflection, Houston \&Warner (2000, p. 73). This is expected to facilitate the avoidance of routine and haphazard instruction, which very often characterizes the classroom environment of many not only unprepared but untrained teachers. 
Citing the common thread that runs through a number of research initiatives over the period 1984-1994, Kochran (2000) articulates his findings as:

1)establishing high quality standards for all

2)focusing on teaching for understanding

3)providing a quality learning environment that facilitates success for all children

4)stressing active, applied learning that focuses on processes, higher level thinking, and the integration of subject matter

5)developing collaborative governance structures

6)forming connections among and between content areas, people, and institutions

7)enhancing the professional status of teachers, teaching, and teacher education.

This world is both more technologically and more multiculturally rich and complex than ever before in history (Ducette, Sewell, \& Shapiro, as cited in Murray, 1996), and teacher education must be aware of these changes and structure their programs to reflect these accordingly.

As a recommendation from research conducted on "cross-ethnic and cross-racial dynamics of instruction," Duhon \& Manson (2000) suggest the need for multicultural collegiate training, while Dilworth (1992) and Obidah and Teel (2001) suggest that the professional preparation of teachers must include additional academic knowledge related to diversity and multicultural contexts, which can be incorporated in the professional education curricular and the clinical teaching experiences.

In the many calls for reform in teacher education, there has been a focus on collaborative partnerships between schools and universities (Carnegie Forum, 1986; Holmes Group, 1986; Kennedy, 1992; Levine, 1992; Thomas, 2002). Most of these reform initiatives are geared toward partners working cooperatively in a mutually beneficial relationship.

McIntyre (1994) stresses that the ultimate goal of encouraging collaboration and establishing partnership is to improve the educational opportunities of school-age children and the initial and continuing preparation of their teachers.

Of first importance in curriculum is to specify a conceptual framework, which should define the professional commitment, dispositions, and values that support the program (NCATE, 1995). The framework, according to Feiman-Nemser (1990), will give direction to the practical activities of teacher preparation, such as program planning, course development, instruction, supervision, and evaluation.

Evans (2000) comments that subject matter knowledge, pedagogical content knowledge, and curricular knowledge are all essential to good teaching.

According to Hollins \& Guzman (2005):

Field experiences are the key components of preparation where prospective teachers learn to bridge theory and practice, work with colleagues and families and develop pedagogical and curricular strategies for meeting the learning needs of a diverse population. (p. 493)

Guyton \& McIntyre (1990) suggest that if teacher education institutions are to succeed in providing prospective teachers with skills and knowledge needed for effective performance, the experience provided in the classroom must correspond to the goals established for the entire program.

The national study done by Goodlad (1990) revealed that many universities did not control the placement of student teachers, which was very often based on convenience rather than on what would provide quality experience.

McIntyre et al. (1996) bemoan the fact that some principals place students with weak cooperating teachers with the hope that the student teachers will positively influence these teachers through their own teaching skills. One wonders about the merit of placing a student teacher with a weak or inexperienced teacher? If both are inexperienced, then who will lead? Undoubtedly, the result may be destructive for all involved.

To ensure quality in teaching, Wise (1999) suggests that the time has come for the teaching profession to embrace a system of quality assurance where the standards are found within three interconnected mechanism: that prepare teachers; professional accreditation of institutions that prepare teachers, performance-based licensing (Roth, 1996), and certification of accomplished teachers. 
Kostner \& Dengerink (2001) write that the quality of teaching depends in large measure on the quality of the teachers, the quality of the teachers depends in large measure on the quality of their professional development, the quality of teacher education depends in large measure on the quality of those who provide it, namely- the teacher educators. (p. 265)

Ducharme (1993) agrees that it is the responsibility of teacher educators to prepare competent teachers for the nation's schools. The Holmes Group (1986) describes such teachers as those who possess broad and deep understanding of children, the subjects they teach and the world around them. They exemplify the critical thinking they strive to develop in their students. ... They do not bore, confuse nor demean; instead they push them to interact with important knowledge and skill. ... For competent professionals, students' learning is the sine quo non of teaching and schooling. (pp. 28-29)

The National Board for Professional Teaching Standards (NBPTS) identifies five basic characteristics regarding professional and effective teaching: teachers' commitment to students and their learning, teachers' knowledge of the subjects they teach and how to teach those subjects to all students, teachers' responsibility for managing and monitoring student learning and teachers thinking systematically about their own practice and being members of learning communities.

\section{Design and Methodology}

This study facilitated a review of three programs' characteristics with a view to understanding their current structure, to provide a comparative analysis of the programs' components, and to unearth information that will be relevant and beneficial to the continued development of pre-service teacher education in Jamaica.

The questions to which answers were sought were as follows:

1) What are the major components of effective/productive teacher education programs?

2) What assessment techniques are effective for teacher education programs?

3) How should teacher pre-service teacher education curriculum be linked to the practice of education?

4) What characteristics are common to the ideal teacher graduate?

5) How should field experiences be organized to effect the implementation of pedagogical content learned by the student teacher?

6) What relationship should exist between the university/college and the practicing schools?

7) What characteristics are common to the ideal teacher educator?

8) What are students' expectations of pre-service teacher education programs?

Three different contexts of preservice teacher education programs were examined in Jamaica and Michigan. Two of the programs were selected from institutions that are publicly operated, while the other was selected from private, Christian denominational institutions. The sample was drawn from those in Jamaica that are certified by the Joint Board of Teacher Education in collaboration with the University of the West Indies, the Ministry of Education and the University Council of Jamaica, while in Michigan, those that are approved by the Michigan Department of Education, and accredited by National Council for Accreditation of Teacher Educators (NCATE).

This study employed five separate interview schedules for the purpose of: (a) gathering information pertinent to the nature, content, and structure of the three pre-service teacher education programs that were studied, (b) ascertaining the perspective of various persons regarding the quality and effectiveness of the program to which they are and were affiliated. Five different categories of individuals in the pre-service teacher education programs were sampled from each program: the program directors, one teacher educator, five senior students, one recent graduate and one cooperating teacher.

The interviews were semi-structured and open-ended with pre-arranged questions. This was done to maximize comparability across the three programs and to allow each interviewee the opportunity to respond to the same questions. In this way, the possibility of extracting more or less information from each person was greatly reduced. In order to maintain accuracy, each interview session was recorded electronically. Interviews were done individually and as focus groups.

The persons who were interviewed were: the directors of the three programs, one teacher educator from each program, five pre-service senior students in each program, one recent graduate in-service teacher from each program, and one cooperating teacher representing each program. 
The program directors provided information relative to the characteristics and structure of their program. The teacher educators addressed the importance of standards for ensuring quality teaching. In addition, they described the qualification that is necessary for instruction at the tertiary level of teacher education as well as insight regarding the curriculum, field experiences, assessment, and characteristics or attributes that should describe the ideal teacher graduate.

The senior students made honest evaluations about their individual programs and the extent to which their expectations and needs were currently being met. They highlighted what they believe were the weaknesses and strengths of their programs and how in their estimation they could be improved.

The graduates who were employed were asked to describe how well their training had prepared them to function effectively in the education system. The strengths and weaknesses or limitations of their training in respect of their perception of field experiences, theory, subject-specific pedagogical knowledge, and actual practice were highlighted.

The cooperating teachers spoke to their perception of their roles as cooperating teachers in the training of pre-service teachers. In addition, they were asked to describe the importance of field experiences for the transfer of content and pedagogical knowledge and for students to hone their skills in classroom management and instruction.

In order to supplement information received from the interviews, a variety of documents were used for this study. These constituted; program handbooks, program development material, field experience handbooks, curriculum documents, and State and Joint Board Regulations.

\section{Data Analysis}

In order to complete a comparative analysis of the information received, a cross-case analysis of the interview protocol in relation to the questions that formed the basis of this research was conducted. The research questions focused on one main area of pre-service teacher education: "The Components." This was further divided into seven areas for the purpose of collecting data. These areas were:

1) Curriculum

2) assessment

3) teacher educators

4) teacher graduates

5) field experiences

6) school/university/college relationship

7) program effectiveness.

The following is an indication of the themes that emerged from this analysis according to the various areas addressed:

Major components of effective pre-service teacher education programs (six themes):

(a) Strong Content Knowledge, (b) Professional Development, (c) Assessment, (d) General Education, (e) Contextualization, and (f) Conceptual Framework.

Legitimacy of assessment in pre-service teacher education and the techniques that would be rendered effective within the context of accountability, accreditation, and the preparation of prospective teachers for K-12 classrooms (five themes): (a) Standards for Accountability, (b) Program Restructuring, (c) Improvement of Teaching and Learning, (d) Continuity, and (e) Authenticity.

Pre-service teacher education curriculum within the context of the practice of education (three themes):

(a) Meaningfulness and Relevance, (b) Diversity Issues, (c) Research.

Characteristics that should describe graduates of pre-service teacher education programs (eight themes):

(a) Involvement in Action Research, (b) Reflective Practice, (c) Good Human Relations Skills, (d) Planning and Organizational Skills, (e) Knowledge of Content, (f) Knowledge of Pedagogy, (g) Cultural Competence, and (h) Student-Centered Perspective.

Importance of and organization of field experiences for the effective implementation and practice of knowledge and pedagogical and professional content learned by student teachers (six themes): 
(a) Collaboration between Host Schools and University/College, (b) Intelligent Choice of Cooperating Teachers, (c) Awareness of Responsibilities of Cooperating Teachers, (d) Placing Students Suitably, (e) Adequate Time for Practice, (f) Coherence Between Field Experience and Content and Pedagogical Knowledge. These are discussed below.

The relationship that should exist between the university/college and practicing schools (three themes):

(a) Close Collaboration, (b) Open Lines of Communication, and (c) Training for Host School Participants.

Criteria for faculty recruitment and the qualities students expect from them (five themes):

(a) Model Instructional Techniques, (b) Scholarly Research Engagement, (c) Expert Current Content Knowledge, (d) Experience in K-12 Classrooms, (e) Cultural Competence.

Students' expectations of effective pre-service teacher education programs (seven themes):

(a) Program adequately structured to facilitate students' involvement in adequate research for the completion of assignments and development of research skills, (b) adequate practicum experience in real classrooms, (c) program coherence between theories and practical experiences, (d) knowledge suitable for addressing students' needs at all levels and to cope with the challenges of today's schools, (e) competent professors who model effective teaching strategies in their classrooms, (f) cutting edge technological awareness, and (g) classroom management and assessment skills.

\section{Summary of Findings across Institutions}

A summary of the responses to the research questions reveals the similarities and differences according to the emphasis that the institutions placed on each of the themes that emerged. Table 1 presents a visual representation of how the themes were recognized across the three institutions identified as, 1- N C University, 2- The M College, and 3- E M University.

The following are those themes that have been identified from discussions across the three institutions according to the categories represented by the research questions. Some themes, as the table indicates, have been mentioned three times, and are common across the three programs; others have been identified twice, while a few were mentioned only once.

Themes that were mentioned only once should not be regarded as least in importance or insignificance. It must be remembered that all the programs, though similar in many respects, are also different in context, structure, and operational paradigm. A particular theme may be emphasized more or less because of this contextual influence.

Components: For this category, assessment and conceptual framework were identified across the three institutions, while strong content knowledge and professional development were identified by two. General knowledge, although evidently a characteristic of each institution, and contextualization were mentioned by only one.

Table 1. Ratings of themes according to program responses

\begin{tabular}{|c|c|c|c|c|}
\hline \multirow[t]{2}{*}{ Research Questions } & \multirow[t]{2}{*}{ Response Themes } & \multicolumn{3}{|c|}{ Institutions } \\
\hline & & 1 & 2 & 3 \\
\hline 1 & Strong Content Knowledge & $\mathrm{x}$ & & $\mathrm{x}$ \\
\hline \multirow[t]{5}{*}{ Components } & Professional Development & $\mathrm{x}$ & & $\mathrm{x}$ \\
\hline & Assessment & $\mathrm{x}$ & $\mathrm{x}$ & $\mathrm{x}$ \\
\hline & General Knowledge & $\mathrm{x}$ & & \\
\hline & Contextualization & & $\mathrm{x}$ & \\
\hline & Conceptual Framework & $\mathrm{x}$ & $\mathrm{x}$ & $\mathrm{x}$ \\
\hline 2 & Standards for Accountability & $\mathrm{x}$ & $\mathrm{x}$ & $\mathrm{x}$ \\
\hline \multirow[t]{4}{*}{ Assessment } & Program Restructuring & $\mathrm{x}$ & $\mathrm{x}$ & $\mathrm{x}$ \\
\hline & Improvement of Teaching and Learning & $\mathrm{x}$ & $\mathrm{x}$ & $\mathrm{x}$ \\
\hline & Continuity & $\mathrm{x}$ & $\mathrm{x}$ & $\mathrm{x}$ \\
\hline & Authenticity & $\mathrm{x}$ & $\mathrm{x}$ & $\mathrm{x}$ \\
\hline 3 & Meaningful and Relevance & $\mathrm{x}$ & $\mathrm{x}$ & $\mathrm{x}$ \\
\hline \multirow[t]{2}{*}{ Curriculum } & Diversity Issues & & $\mathrm{x}$ & $x$ \\
\hline & Research Based & $\mathrm{x}$ & $\mathrm{x}$ & $\mathrm{x}$ \\
\hline
\end{tabular}




\begin{tabular}{|c|c|c|c|c|}
\hline 4 & Involvement in Action Research & $\mathrm{x}$ & $\mathrm{x}$ & $\mathrm{x}$ \\
\hline Teacher & Reflective Practice & & $\mathrm{x}$ & $\mathrm{x}$ \\
\hline \multirow[t]{7}{*}{ Graduates } & Good Human Relations Skills & $\mathrm{x}$ & & $\mathrm{x}$ \\
\hline & Planning and Organizational Skills & $\mathrm{x}$ & & $\mathrm{x}$ \\
\hline & Knowledge of Content & $\mathrm{x}$ & & $\mathrm{x}$ \\
\hline & Knowledge of Pedagogy & $\mathrm{x}$ & $\mathrm{x}$ & $\mathrm{x}$ \\
\hline & Cultural Competence & $\mathrm{x}$ & $\mathrm{x}$ & $\mathrm{x}$ \\
\hline & Student-Centered Perspective & & $\mathrm{x}$ & \\
\hline & Collaboration between Host Schools and & $\mathrm{x}$ & $\mathrm{x}$ & $\mathrm{x}$ \\
\hline 5 & University/College & & & \\
\hline Field & Intelligent Choice of Cooperating Teachers & $\mathrm{x}$ & $\mathrm{x}$ & $\mathrm{x}$ \\
\hline \multirow[t]{4}{*}{ Experiences } & $\begin{array}{l}\text { Awareness of the Responsibilities of Cooperating } \\
\text { Teachers }\end{array}$ & $\mathrm{x}$ & $\mathrm{x}$ & $\mathrm{x}$ \\
\hline & Placing Students Suitably & $\mathrm{x}$ & $\mathrm{x}$ & $\mathrm{x}$ \\
\hline & Adequate Time for Practice & $\mathrm{x}$ & $\mathrm{x}$ & $\mathrm{x}$ \\
\hline & Coherence Between Field Experience and Content ... & $\mathrm{x}$ & $\mathrm{x}$ & $\mathrm{x}$ \\
\hline 6 & Close Collaboration & $\mathrm{x}$ & $\mathrm{x}$ & $\mathrm{x}$ \\
\hline School/University/ & Open Lines of Communications & $\mathrm{x}$ & $\mathrm{x}$ & $\mathrm{x}$ \\
\hline College Relationship & Training for Host Schools Participants & $\mathrm{x}$ & $\mathrm{x}$ & $\mathrm{x}$ \\
\hline 7 & Model Instructional Techniques & $\mathrm{x}$ & $\mathrm{x}$ & $\mathrm{x}$ \\
\hline Teacher & Scholarly Research Engagement & $\mathrm{x}$ & $\mathrm{x}$ & $\mathrm{x}$ \\
\hline \multirow[t]{3}{*}{ Educators } & Expert Current Knowledge & $\mathrm{x}$ & & $\mathrm{x}$ \\
\hline & Experience in K-12 Classrooms & $\mathrm{x}$ & $\mathrm{x}$ & $\mathrm{x}$ \\
\hline & Cultural Competence & & & $\mathrm{x}$ \\
\hline 8 & Program Adequately Structured to Facilitate ... & & $\mathrm{x}$ & \\
\hline Program Effectiveness & Adequate Practicum in Real Classrooms & $\mathrm{x}$ & $\mathrm{x}$ & $\mathrm{x}$ \\
\hline and Students' & Knowledge Suitable for Addressing Students' & $\mathrm{x}$ & & $\mathrm{x}$ \\
\hline \multirow[t]{5}{*}{ Expectations } & Needs ... & & & \\
\hline & Competent Professors who Model Effective & $\mathrm{x}$ & $\mathrm{x}$ & $\mathrm{x}$ \\
\hline & Teaching ... & & & \\
\hline & Cutting-edge Technological Awareness & & $\mathrm{x}$ & $\mathrm{x}$ \\
\hline & Classroom Management and Assessment Skills & & & $\mathrm{x}$ \\
\hline
\end{tabular}

Assessment: For this category, all the themes were identified across all three institutions.

Curriculum: For this category, all the themes were identified across all the three institutions.

Teacher Graduates: For this category, involvement in action research, knowledge of pedagogy, and cultural competence were mentioned across the three programs. Reflective practice, good human relations skills, and planning and organizational skills were identified across two programs, while knowledge of content identified and student-centered perspective by one.

Field Experiences: All six themes were identified across the three institutions; collaboration between host schools and university/college, intelligent choice of cooperating teachers, awareness of the responsibilities of cooperating teachers, adequate time for practice, coherence between field experiences, content and pedagogical knowledge, and placing students suitably.

School/University/College relationship: All three themes were identified across the three institutions: close collaboration, training for host-school participants, and open lines of communication.

Teacher Educators: Of the five themes identified under this category, three were identified across the three institutions; model instructional techniques, scholarly research engagement, and experience in K-12 classrooms. Expert current knowledge was identified by two, while cultural competence was identified by only one.

Students' Expectations and Program Effectiveness: For this category, adequate practicum in real classrooms and competent professors who model effective teaching strategies in their classrooms were identified across all three institutions. Knowledge suitable for addressing students at all levels and cutting-edge technological awareness were identified by two, while program adequately structured to facilitate students involvement in 
adequate research and the development of research skills, and classroom management and assessment skills were identified by only one institution.

The students were generally satisfied that their program was adequate and it prepared them well to function effectively in the schools. They were impressed with the performance of their lecturers/professors who were quite personable, modeled interesting and innovative instructional strategies, and used a variety of alternative assessment techniques. In general, they felt that their courses/content was relevant for K-12 classroom environment and they could relate most of what they learned to what they had to teach.

For program improvement, they would provide more experience in student teaching instead of doing unnecessary courses that are not relevant to classroom teaching; change some of the advising rules to facilitate new and older students who get lost in the program, especially when they have transferred from other universities; provide more guidance to students, especially in course selection so they do not complete courses then discover that they become obsolete soon afterwards; make advisors more aware of what goes on in the university, so they will be able to provide the kind of information that students need.

\section{Summarized Discussion of Findings Based on Research Questions}

For this section, the themes that emerged across the three programs in response to the categories representing the research questions have been summarized according to the regularity with which they have been mentioned. Those that were common to the three programs will be identified first, those mentioned in two programs second, and those mentioned in only one program will be noted last.

\subsection{Research Question 1}

The first question asked: What are the major components of effective/productive teacher education programs? The data produced six components.

\subsubsection{Assessment and Conceptual Framework}

Assessment has to be integral to pre-service teacher education. It should serve as a measure of accountability and must be authentic to the degree to which it is meaningful for the purpose for which it was established. Pre-service teacher education programs should be built on a conceptual framework that is clearly articulated. It should be fundamental to the organization as it provides the basis for all areas of program structure and development.

\subsubsection{Strong Content Knowledge and Professional Development}

Pre-service teacher education programs need to be built on a strong content knowledge that will provide the fundamental basis on which the various areas of the teaching profession will be built. The professional development of teachers should be embedded in pre-service teacher education programs. Teachers will develop a repertoire of instructional skills, they will understand the psychology of child and adolescent development and learning, they will develop expertise in their areas of specialization, and they will develop interpersonal skills and lifelong learning attitudes towards their own growth and development.

\subsubsection{General knowledge and Contextualization}

Knowledge for enrichment is critical to pre-service teacher education. Prospective teachers need to be empowered with general knowledge that will facilitate their own professional growth and provide their students with some level of experience with various subject matters of human conversation. Preparatory programs should depict the shared patterns of institutions, behaviors, traditions, values, and beliefs.

Professional education should therefore train educators to place students and their culture at the center of learning, to acknowledge, respect, and build on the knowledge, beliefs and experiences that students bring with them to the classroom and to affirm rather than negate the value of students' culture. As far as possible, the programs should be highly reflective of the context within which students are expected to operate and serve.

\subsection{Research Question 2}

The second question asked: What assessment techniques are effective for teacher education programs? The data produced five themes, which have all been emphasized across all three programs with respect to the importance of assessment and the techniques that are most suitable for pre-service teacher education. They have been itemized for discussion and not according to level of importance. 


\subsubsection{Standards for Accountability}

The place of assessment in pre-service teacher education has already been validated. Assessment denotes a measure of accountability and this should ensure that programs are based on measurable standards which are representative of good learning outcomes.

\subsubsection{Program Restructuring}

Assessment is critical to program evaluation and reform. It is by virtue of assessment that administrators are able to determine whether or not they are achieving their program goals in respect to learning outcomes for prospective teachers and K-12 students, community service, and research engagement.

\subsubsection{Improvement of Teaching and Learning}

Assessment ensures teachers engage in thoughtful, reflective, continuous evaluation of their work within the context of the teaching-learning environment at all levels of the education system. Prospective teachers should be exposed to a variety of learning experiences and assessment techniques and they in turn will understand how to organize similar and suitable experiences for their students.

\subsubsection{Continuity}

If teaching and learning is continuous, then it follows that assessment must be continuous also. In order to monitor the learning experiences of students at all educational levels, some measure of assessment has to be administered during and also at the end of the experience. Assessment should be formative as well as summative.

\subsubsection{Authenticity}

The extent to which the assessment serves its purpose, whether for self-evaluation, improvement of teaching and learning, program evaluation, denoting accountability standards, or providing for certification, will determine its authenticity. Assessment has to be authentic if the results are to be used intelligently for reform in preservice teacher education. A variety of alternative techniques should be used in pre-service teacher education and these ought to be chosen dependent on the purpose and nature of the information that is being sought.

\subsection{Research Question 3}

The third question asked: How should pre-service teacher education curriculum be linked to the practice of education? The data produced three themes which were emphasized across all three programs. These have been itemized for discussion and not according to any measure of importance.

\subsubsection{Meaningfulness and Relevance}

Programs for the education of prospective teachers should be characterized in all respects by the conditions of learning that they are to establish in their own schools and classrooms. The curriculum should be meaningful and relevant to societal dynamics and make prospective teachers capable of influencing their students' lives to meaningful ends.

\subsubsection{Diversity Issues}

The pre-service teacher education curriculum has to be suitable for the preparation of teachers who are culturally competent or culturally aware. If teachers are to be successful in the classroom, they should be able to teach all children, and only culturally competent teachers or those who are aware of diversity issues will be able to adequately and/or successfully address the needs of all their students. Programs have to be reflective of, and address multicultural and/or diversity issues.

\subsubsection{Research Based}

Pre-service teacher education should be informed by accurate research. This knowledge should be diverse and should form a solid base on which curriculum and other program components are built.

\subsection{Research Question 4}

The fourth question asked: What characteristics are common to the ideal teacher graduate? The data produced eight dispositions:

\subsubsection{Involvement in Action Research, Knowledge of Pedagogy, and Cultural Competence}

These were identified across all three programs. Successful teachers engage in and rely on research and inquiry to inform their practice. Prospective teachers should be exposed to and given the opportunity to be involved in action research during their period of preparation. Teachers are very important in the classroom and their performance there will depend to a great extent on how much they are able to be reflective in their teaching. 
A repertoire of pedagogical skills is needed for successful teaching in the K-12 diverse classrooms of today's schools. Beginning teachers need to be aware of subject-specific pedagogy as well as general pedagogy. They should also be knowledgeable of pedagogy appropriate for the content area they will teach.

If no child is to be left behind in the educational arena, then there must be quality teachers in all classrooms. In order to teach all children successfully, teachers have to be culturally competent. It is important that prospective and beginning teachers acquire such skills. If programs take diversity issues into consideration, then it follows that prospective teachers will eventually become culturally competent

6.4.2 Reflective Practice, Good Human Relations Skills, Planning and Organizational Skills, and Knowledge of Content, were Identified Across two Programs

Effective teachers are reflective rather than routine. Beginning teachers are expected to be cognizant that the process of understanding and improving their teaching has to begin with a reflection of their actions and experience in the classroom. The process is never complete and is characteristic of teachers who are really committed to making a difference in their schools and classroom by paying attention to what they say and do. This attitude of reflection will lead to continued involvement in action research.

Creating a warm, pleasant, and comfortable learning environment is a contributing factor to learning and achievement, especially at the K-12 levels. Prospective and beginning teachers need to possess good human relations skills and these must enhance their relationship with all their students.

In order for learning goals to be achieved, teachers are expected to develop the skills to plan and organize their classrooms purposefully in respect of those goals. Planning and organizing an orderly, purposeful environment will minimize distractions and optimize learning. The beginning teacher needs to acquire these management skills.

Beginning teachers need to be cognizant of the fact that their students must be at the center of the learning experience. Within this environment, they become the focus of everything that happens in the classroom. They are active rather than passive and their learning is encouraged and facilitated rather than discouraged and impeded.

Teachers are better able to function at their best when they know and understand their subject matter. With this expert knowledge, they can enrich the learning environment of their students as they are taught to construct, explore, and build their own knowledge base. These teachers earn more credibility and respect from their students.

\subsubsection{Student-centered Perspective}

Students need to be taught to develop the skill of critical thinking and problem solving. They should not be allowed to only parrot and regurgitate their teachers' thoughts and ideas, instead they need to be given the opportunity to develop and express themselves in a teachable classroom atmosphere. They should be motivated in a student-friendly environment.

\subsection{Research Question 5}

The fifth question asked: How should field experiences be organized to effect the implementation of pedagogical content learned by the student teacher? The data produced six themes that were emphasized across all three programs. These have been itemized for discussion and not as an indication of any measure of importance.

\subsubsection{Collaboration between Host Schools and University/College}

A successful field experience begins with a close collaboration between the university/college and the cooperating/participating community schools. It is the responsibility of the university/college to initiate and establish this relationship.

\subsubsection{Intelligent Choice of Cooperating Teachers}

Cooperating teachers are integral to the success of student teachers during field experiences. Because they have a significant impact on their professional career, it is important that they are chosen with utmost care. Only those teachers who are mature, committed, dedicated, and demonstrate good teaching and mentoring skills should be chosen as cooperating teachers.

\subsubsection{Awareness of Responsibilities of Cooperating Teachers}

To be effective, cooperating teachers have to be knowledgeable of their responsibilities. This necessitates some amount of professional training, collaboratively organized by the university/college and the host schools, where principles for guiding the practice and expectations can be duly clarified. 


\subsubsection{Placing Students Suitably}

Student teachers should be strategically placed in environments where they can be emotionally stable and comfortable. In addition, placement should facilitate the use of the skills they have been inculcating specific to their areas of specialization. Convenient placement should be avoided and classroom size should not be too overwhelming for the student teacher. Cooperating teachers and student teachers should be able to work amicably together.

\subsubsection{Adequate Time for Practice}

Student teachers need adequate time in diverse, supervised practiced. Their personal beliefs and previous experiences, some of which may be unconventional and negative, will most definitely be brought to bear on the practice. Consequently, there should be time enough for some, if not all of these to be altered for the better. What is adequate may depend on the culture and structure of the various programs.

\subsubsection{Coherence between Field Experience and Content and Pedagogical Knowledge}

Good preservice teacher education programs are coherent. Courses, assignments, and field experiences are organized around a particular frame of reference, philosophy, or vision, and students are able to see the linkages in the learning experience. What students learn in college or university courses should be linked in some way to what they are expected to do in their own classrooms.

\subsection{Research Question 6}

The sixth question asked: What relationship should exist between the university/college and the practicing schools? The data produced three distinguishing features and these were identified across all three programs. They have been itemized for discussion and not to indicate any level of importance.

\subsubsection{Close Collaboration}

Collaborative partnerships between community schools and universities/colleges are recommendations for reform initiatives in teacher education. These partnerships are geared toward partners working cooperatively in a mutually beneficial relationship. If universities/colleges are preparing teachers for community schools, then both entities need to have a common understanding of societal dynamics and goals in respect to the education of children.

\subsubsection{Open Lines of Communication}

The ideal student teaching experience should be characterized by many opportunities for consultation and the sharing of ideas and information both formally and informally. There should be continuous dialogue between the cooperating teacher and the student teacher, the college/university supervisor and the student teacher, and the cooperating teacher and the university/college supervisor.

\subsubsection{Training for Host-School Participants}

It should be regarded as a tremendous and important responsibility to partner in the education of teachers. Host schools should be made to understand that they are important in this triad and in respect of that, they need to be included in collaborative planning for training and development.

\subsection{Research Question 7}

The seventh question asked: What characteristics are common to the ideal teacher educator? The data produced five characteristics/dispositions. Three were identified across all three programs, while one was identified by two programs, and the remaining by one program.

\subsubsection{Model Instructional Techniques, Scholarly Research Engagement, and Experience in K-12 Classrooms}

Professors/lecturers should be exemplified by their expertise in modeling of curricular and instructional practices in pre-service teacher education. Their learning environment must be enriching and fulfilling for those who are future teachers in K-12 classrooms. They are expected to demonstrate teaching skills in much the same way they expect their students to operate.

Pre-service teacher education has to be informed by a strong knowledge base. It is information from research engagement that will support this knowledge base and clarify and strengthen faculty beliefs regarding the various aspects of teacher education to which they are directly involved. Fundamentally, pre-service teacher educators' major responsibility is to enable prospective teachers to develop into competent teachers.

Consequently, if they are to be instrumental in enhancing this development of competence in their students, they themselves need to be competent in their areas of specialization. These include among other things: content, 
pedagogy, organization, group dynamics, and communicative, developmental, and personal growth. Experience in K-12 classrooms will certainly enhance this growth.

\subsubsection{Expert Current Content Knowledge}

The time has come for teacher educators to reorganize, restructure, and redefine their knowledge base so that they will be in a better position to operate not as teachers of K-12 students, but as teachers of teachers. Their knowledge has to be current and extensive in order for them to effectively prepare teachers for the challenges they will face in their profession.

\subsubsection{Culturally Competent}

Effective pre-service teacher education programs have the challenging task of preparing all prospective teachers to teach a culturally diverse group of students. The need for culturally competent professors is salient within programs that are purposefully structured to achieve this goal. There definitely cannot be culturally competent prospective teachers without culturally competent professors.

\subsection{Research Question 8}

This section required the students to do a critical evaluation of their program with respect to their expectations and in comparison to what their program provided. In general, they concurred that their individual programs had strong as well as weak areas, but did indeed give them overall preparation. Although they agreed that there were areas that needed improvement, they were basically satisfied that they were provided with a fairly solid foundation on which they can build successful careers.

The data representing the expectations they had for their programs revealed seven components:

6.8.1 Program Adequately Structured to Facilitate Students' Involvement in Adequate Research for The Completion of Assignments and Development of Research Skills

Students expected pre-service teacher education programs to be organized and structured to enhance and facilitate their development of research skills. Although they anticipated that their programs would be rigorous, they expected that it would be structured to allow them enough time for engagement in their own research.

\subsubsection{Adequate Practicum Experience in Real Classrooms}

Students expected to be allowed adequate practice for their field experiences in real classroom situations.

\subsubsection{Program Coherence between Theories and Practical Experiences}

Students expected their teacher education programs would prepare them to function in the real world with all the challenges. They needed to see a relationship between the theory they learned and the practice in the field.

6.8.4 Knowledge Suitable for Addressing Students' Needs at All Levels and to Cope with the Challenges of Today's Schools

Students expected that their training program should make them knowledgeable and competent enough to address their students' needs in today's diverse classrooms.

\subsubsection{Competent Professors who Model Effective Teaching Strategies in Their Classrooms}

Students expressed a high regard for faculty members who demonstrate competence in their classroom delivery and display overall professional development. Consequently, they expected their professors to be able to model a plethora of instructional strategies that are applicable for use in K-12 classrooms.

\subsubsection{Cutting-edge Technological Awareness}

In this age of advanced technology, students expected to be taught how to explore the information highway. They also expected to be introduced to innovative ways of using the computer and other forms of technology to enhance their classroom delivery and professional development.

\subsubsection{Classroom Management and Assessment Skills}

Students expected to be taught classroom management skills as they believe that this is critical to success in the K-12 classroom.

For program improvement, students suggested that the programs should: provide more experience in student teaching instead of doing unnecessary courses that are not relevant to classroom teaching; change some of the advising rules to facilitate new and older students who get lost in the program, especially when they have transferred from other universities; provide more guidance to students, especially in course selection so they do 
not complete courses then discover that they become obsolete soon afterwards; make advisors more aware of what goes on in the university, so they will be able to provide the kind of information that students need.

\section{Conclusions}

The following are the conclusions which have been drawn from the results of this study with respect to the eight research questions. The major components of effective/productive teacher education programs are:
1)
Assessment
2)
Conceptual Framework
3) Strong Content Knowledge
4) Professional Development
5) General knowledge
6) Contextualization.

Assessment techniques are critical for effective pre-service teacher education programs. The process should ensure that the following program elements are present:
1) Standards for Accountability
2) Program Restructuring
3) Improvement of Teaching and Learning

Furthermore, Assessment should be characterized by the following hallmarks:

1) Continuity

2) Authenticity

3) Employment of traditional as well as alternative methods.

Pre-service teacher education curriculum should be linked to the practice of education. It should demonstrate or address the following:
1) Meaningfulness
2) Relevance
3) Diversity Issues
4) Research Focus.

Ideal teacher graduates should display the following dispositions:
1) Involvement in Action Research
2) Knowledge of Pedagogy
3) Cultural Competence
4) Reflective Practice
5) Good Human Relations Skills
6) Planning and Organizational Skills
7) Knowledge of Content
8) Student-centered Perspective.

Field experiences should be organized to effect the implementation of pedagogical content learned by the student teacher. There needs to be the following elements:

1) Collaboration between Host Schools and the University/College

2) Intelligent Choice of Cooperating Teachers

3) Awareness of the Responsibilities of Cooperating Teachers

4) Adequate Time for Practice

5) Coherence between Field Experience and Content and Pedagogical Knowledge

6) Suitable Placement for Practicing Students.

The relationship between the university/college and the practicing schools should be characterized by: 
1) Close Collaboration

2) Open Lines of Communication

3) Training for Host-School Participants.

The ideal teacher educator should possess the following skills:

1) Model Instructional Techniques

2) Demonstrate Scholarly Research Engagement

3) Experience in K-12 Classrooms

4) Expert Current Content Knowledge

5) Cultural Competence.

The following are students' expectations of pre-service teacher education programs:

1) Adequately structured to facilitate their involvement in adequate research for the completion of assignments and development of research skills

2) Adequate practicum experience in real classrooms

3) Program coherence between theories and practical experiences

4) Knowledge suitable for addressing their needs at all levels and to cope with the challenges of today's schools

5) Competent professors who model effective teaching strategies in their classrooms

6) Cutting-edge technological awareness

7) Classroom management and assessment skills.

\section{References}

Brimley, V., \& Garfield, R. R. (2002). Financing education in a climate of change. Boston, MA: Allyn \& Bacon.

Byrd, D., \& McIntyre, D. (1997). Research on the education of our nation's teachers. Thousand Oaks, CA: Corwin Press.

Carnegie Forum on Education and the Economy. (1986). A nation prepared: Teachers for the 21st century; The report of the task force on teaching as a profession. New York: Carnegie Corporation.

Dilworth, M. E. (1992). Diversity in teacher education: New expectations. San Francisco: Jossey-Bass.

Ducharme, E. R. (1993). The lives of teacher educators. New York: Teachers College Press.

Duhon, G., \& Manson, T. (2000). Implications for teacher education cross-ethnic and cross-racial dynamics of instruction. Lampeter: Edwin Mellen Press.

Evans, H. (2000). Learning to teach, learning from teaching. In M. Brown (Ed.), Dimensions of teaching and learning: Caribbean experience. Kingston, Jamaica: University of the West Indies.

Feiman-Nemser, S. (1990). Teacher preparation: Structural and conceptual alternatives. In W. R. Houston (Ed.), Handbook of research on teacher education. New York: Macmillan.

Fullan, M. (1995). Context: Overview and framework. In M. J. O'Hare \& S. J. Odell (Eds.), Educating teachers for leadership and change in teacher education yearbook. Thousand Oaks, CA: Corwin Press.

Goodlad, J. I. (1990). Better teachers for our nation's schools. Phi Delta Kappa, 72(3), 185-194.

Goodlad, J. I. (1994). Educational renewal: Better teachers, better schools. San Francisco, CA: Jossey-Bass.

Guyton, E. (2000). Powerful teacher education programs. In D. J. McIntyre \& D. M. Byrd (Eds.), Research on effective models for teacher education. Thousand Oaks, CA: Corwin Press.

Guyton, E., \& McIntyre, D. J. (1990). Student teaching and school experiences. National Council for Accreditation of Teacher Education. (1995a). A guide to college to programs in teacher preparation. Washington, DC: Author.

Hollins, E., \& Guzman, M. (2005). Research on preparing teachers for diverse populations. In M. CochranSmith \& K. Zeichner (Eds.), Studying teacher education: The report of the AERA Panel on research and teacher education. Mahwah, NJ: Lawrence Erlbaum. 
Holmes Group. (1986). Tomorrow's teachers. East Lansing, MI: Author.

Houston, W. R., \&Warner, A. R. (2000). Inquiry and reflection: Twin needs for improved teacher education. In D. J. McIntyre \& D. M. Byrd (Eds.), Research on effective models for teacher education. Thousand Oaks, CA: Corwin Press.

Jennings, Z. (2000). Constraints on content and methodology preparation: Commonwealth Caribbean teachers college. In M. Brown (Ed.), Dimensions of teaching and learning: The Caribbean experience. Kingston, Jamaica: University of the West Indies.

Joint Board of Teacher Education. (2003). Regulations for teacher certification. Kingston, Jamaica: University of the West Indies.

Kennedy, M. (1992). Establishing professional schools for teachers. In M. Levine (Ed.), Professional practicing schools: Linking teacher education and school reform. New York: Teachers College Press.

King, R. (1998). Educational inequality in Jamaica: The need for reform. Kingston, Jamaica: The University of the West Indies.

King, R. (2000). Violence and schools in Jamaica: Historical and comparative perspective. In H. Evans (Ed.), Institute of education annual. Kingston, Jamaica: The University of the West Indies.

Kochran, F. K. (2000). Models for enhancing the professional development of teachers. In D. J. McIntyre \& D. M. Byrd (Eds.), Research on effective models for teacher education. Thousand Oaks, CA: Corwin Press.

Kostner, B., \& Dengerink, J. (2001). Towards a professional standard for Dutch teacher education. European Journal of Teacher Education, 25(2), 264-267.

Levine, M. (1996). Educating teachers for restructured schools. In F. B. Murray (Ed.), The teacher educator's handbook: Building a knowledge base for the preparation of teachers. San Francisco: Jossey-Bass.

McIntyre, D. J. (1994). Context: Overview and framework. In M. J. O’Hare \& S. Odell (Eds.), Partnerships in education. Fort Worth, TX: Harcourt Brace

McIntyre, D. J., Byrd, D. M., \& Foxx, S. M. (1996). Field and laboratory experiences. In J. Sikula, T. Buttery, \& E. Guyton (Eds.), Handbook of research on teacher education. New York: Prentice Hall.

Michigan Department of Education. (2003). The Michigan definition for identifying highly qualified teachers. Retrieved from Michigan.gov/documents/definitionofhighlyqualifiedteachers_63281_7.pdf

Miller, L., \& Silvernail, D. (1994). Wells junior high school: Evolution of a professional development school. In L. Darling-Hammond (Ed.), Professional development school: Schools for developing a profession. New York: Teachers College Press.

Murray, F. (1996). Teacher educators' handbook. San Francisco: Jossey-Bass.

National Board for Professional Teaching Standards. (1990). Toward high and rigorous teaching standards for the teaching profession: Initial policies and perspectives of the National Board for Professional Teaching Standards (2nd ed.). Washington, DC: Author

O'Hair, J. O., \& Odell, S. J. (1995). Educating teachers for leadership and change. Thousand Oaks, CA: Corwin Press.

Obidah, J., \& Teel, K. M. (2001). Because of the kids: Facing racial and cultural differences in schools. New York: Teachers College Press.

Orlofsky, D. (2001). Redefining teacher education. New York: Peter Lang.

Pacheco, A. (2000). Meeting the challenge of high-quality teacher education. Washington, DC: American Association of Colleges for Teacher Education.

Roth, R. A. (1996). Standards for certification, licensure and accreditation. In J. Sikula (Ed.), Handbook of research on teacher education. New York: Prentice Hall.

Sikula, J. (1996). Handbook of research on teacher education (2nd ed.). New York: Prentice Hall.

Thomas, E. (2002). Teacher education: Dilemmas and prospects. London: Kogan Page.

Wise, A. E. (1999). Moving toward performance-based accreditation systems for the teaching profession. In R. A. Roth (Ed.), the role of the university in the preparation of teachers. Philadelphia: Falmer Press. 


\section{Copyrights}

Copyright for this article is retained by the author(s), with first publication rights granted to the journal.

This is an open-access article distributed under the terms and conditions of the Creative Commons Attribution license (http://creativecommons.org/licenses/by/4.0/). 